\title{
The Impact of the U.S. Military Assistance on the Political Stability in Jordan: 1990-2018
}

\author{
Atallah S. Al Sarhan \\ Hashemite University \\ P.O. Box 330127, Zarqa 13133, Jordan
}

\begin{abstract}
This paper examines the impact of the U.S. military assistance on the political stability in Jordan from 1990-2018. This paper reveals that the U.S.-Jordan military relations date back decades to the early years of the Cold War. This paper argues that the U.S. military assistance to Jordan is a key component in bilateral relations. This paper finds that the U.S. military assistance is principally directed toward enabling the Jordan Armed Forces (JAF) to procure and maintain conventional weapons system. Immediately after 9/11 events of 2001, the Iraq War of 2003, and the rise of the Islamic State of Iraq and Syria (ISIS) in 2013, the U.S. military assistance to Jordan increased extensively to secure the borders, to maintain the country stability, and to control the threat of ISIS. Currently, Jordan is in the top of military assistance recipients in the world, receiving up to \$19.2 billion through FY 2016.
\end{abstract}

Keywords: foreign aid, U.S. military assistance, Islamic State of Iraq and Syria, Jordan, United States.

\section{Introduction}

Following World War II, both the U.S. and the Soviet Union viewed the Middle East, South, and Southeast Asia as prime regions to compete for influence in the Third World (Joshua \& Gibert, 1969). In the very early years of the Cold War, foreign aid (including economic and military assistance) became a principal instrument of the U.S. foreign policy, especially in the Third World. In 1947, Truman's doctrine provided economic aid and military advice to Greece and Turkey to prevent Soviet expansion and the spread of international communism into the Middle East region. In April 1957, Jordan was threatened by communism, necessitating receipt of aid from the U.S and invigorating the relationship between the two nations.

The purpose of this paper is to shed light on the U.S. military assistance provided to Jordan from 1951 to 2018 . This paper strives to explain the role of the U.S. military assistance in advancing the mutual relations between the two nations. Moreover, this paper also discusses the impact of the U.S. military assistance on the political stability in Jordan, most especially after the terrorist attacks of September 11, 2001, the Iraq War of 2003, and the emergence of the Islamic State of Iraq and Syria (ISIS) in 2013.

\section{Background of the U.S. Foreign Aid to Jordan}

The U.S. foreign aid to Jordan dates back decades to the Cold War. The U.S. government has provided economic and military assistance to Jordan since 1951, and this aid was intensified in the late 1950s with the growing fear of the spread of communism in the Middle East and Jordan, in particular. According to the Congressional Research Service, over time the amount of aid that Jordan has received varies depending on various threats at a particular time, political perspectives, and worldwide cuts on funding (Sharp, June 15, 2010). Today, Jordan is in the top ten of foreign aid recipients in the world, having received $\$ 909$ million in military assistance since FY 2014. This figure does not include funds received from the Defense Department's security assistance accounts. In the Middle East, Jordan is third only behind Israel and Egypt, receiving \$19.2 billion through FY 2016 (Sharp, November 14, 2017).

According to the U.S. Agency for International Development (USAID), the U.S. objectives in spreading foreign aid (economic and military) to Jordan can be summed up as follows:

Surrounded by Israel, Syria, Iraq and Saudi Arabia, Jordan is geographically and politically important. Jordan has long supported a comprehensive Middle East peace settlement. Jordan continues to seek a formula which will permit Jordanians and Palestinians to seize the opportunity for peace. The primary objective of Aid's program in Jordan is to assist the continued development of a moderate, Western-oriented state that is socially and politically stable. For [six]ty years, US economic assistance has been an important component of the US presence in Jordan, contributing to the formation of both the physical and human infrastructure which helped foster the rapid socio-economic growth of recent years (Khader \& Badran, 1987, pp. 18-20). 


\section{The U.S. Foreign Military Assistance to Jordan}

Since the early years of the Cold War, the Dwight D. Eisenhower administration pledged to protect the independence and integrity of Jordan from the Soviet Union and national communist threat in the Middle East. Military assistance has been given to Jordan since April 1957, replacing the British subsidies when they withdrew from the country. After the Jordanian Civil War broke out in September 1970, the Richard M. Nixon administration publicly pledged support to save the Jordanian regime. On September 17, 1970, while standing with Israeli Prime Minister Golda Meir, President Nixon pledged that the U.S. would intervene if any power threatened Jordan (Fry, Goldstein, \& Langhorne, 2002). Consequently, the U.S. Sixth Fleet was dispatched to the eastern Mediterranean to protect Jordan, due to its importance to the entire region's security and stability. Since then, Jordan began to rely heavily on the U.S. for military assistance and security and thus, the U.S. has been satisfied to play the role of primary guarantor of Jordan's security (Jamal, 2012).

The U.S. military assistance to Jordan has fluctuated depending on domestic, regional, and international events. In the early 1990s, the U.S. military assistance to Jordan began to dramatically decline due to two reasons: (a) the Soviet Union threat to the Middle East decreased and completely collapsed in late December 1991; (b) Jordan's unwillingness to join the US-led international coalitions against Saddam Hussein and his regime in 1990-1991 was negatively viewed.

According to the Los Angeles Times on June 20, 1991, the U.S. House of Representatives voted to suspend military assistance to Jordan:

The [U.S.] House [of Representatives] voted [on June 20, 1991] to cut off American military aid to Jordan in reprisal for its support of Iraqi President Saddam Hussein during the Persian Gulf War. The lawmakers gave President Bush the authority to waive the cutoff if certain conditions are met, principally bilateral negotiation with Israel (Los Angeles Times, June 20, 1991).

\section{Expanded Defense Articles}

After the Gulf crisis of 1990-1991, and in response to King Hussein's crucial role in the Madrid Peace Conference of 1991, the U.S. military assistance was restored by the mid-1990s. By November 1996, US-Jordan military relations improved to the point that Jordan was declared a 'Major Non-NATO Ally (MNNA)' of the U.S. in the Middle East. This title has significantly enabled Jordan to obtain priority status when it comes to military assistance. In the past five years, this classification made Jordan eligible for surplus U.S. defense items and systems (including two C-130 aircraft, HAWK MEI-23E missiles, and cargo trucks), training, and equipment loans necessary for research (Sharp, December 2, 2014, p. 13 \& November 14, 2017, p. 15). In addition, in FY 1996, Jordan received \$200 million in Foreign Military Financing (FMF) and \$1.2 million in International Military Education and Training (IMET), the primary types of military assistance provided to Jordan.

The U.S. military assistance has increased since Jordan became an MNNA. In FY 1997, Jordan received \$30 million in FMF and \$1.7 million in IMET, increasing to \$75 million in FMF and \$1.6 million in IMET in FY 1998. In FY 1999, Jordan received \$70 million in FMF and \$1.6 million in IMET, as well as \$50 million in FMF as part of the Wye River Agreement Fund. In FY 2000, Jordan received \$75 million in FMF, \$1.6 million in IMET, and \$150 million in FMF as part of the Wye River Agreement Fund (see Table 1).

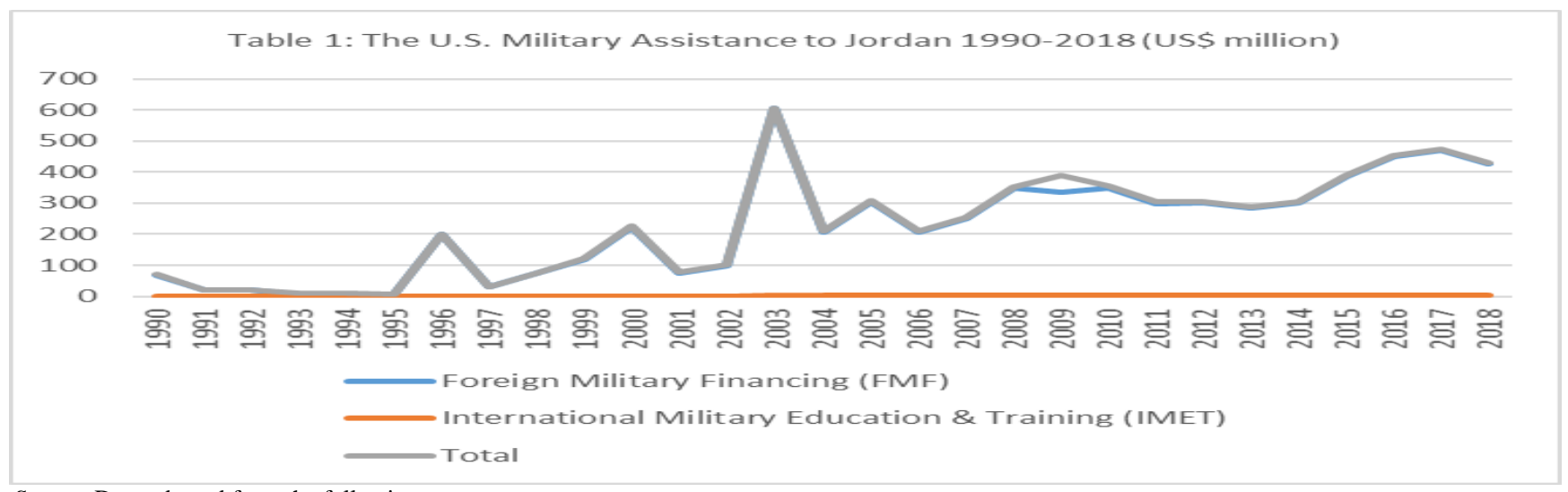

Source: Data adapted from the following sources:

- Knowles, W. (2005). Jordan since 1989: A Study in Political Economy. New York: I.B. Tauris \& Co Ltd., p. 127.

- Sharp, Jeremy M. Jordan: Background and U.S. Relations, CRS Report RL33546. Washington DC: Library of Congress, Congressional Research Service, March 17, 2015, p. 19 \& November 14, 2017, p. 17. 
During the early 2000s, Jordan's military aid increased exponentially. In FY 2001, Jordan received \$75 million in FMF and $\$ 1.7$ million in IMET. In fact, following September 11, 2001, terrorist attacks on the U.S., Jordan pledged support to help the U.S. in its global War on Terrorism and became a combat zone for U.S. military efforts in the area (Arkin, 2005).

In FY 2002, Jordan received \$75 million in FMF and \$2 million in IMET, as well as \$25 million in FMF as part of the Emergency Supplemental Funding. In FY 2003, Jordan received \$198 million in FMF, \$2.4 million in IMET, and an extra \$406 million in FMF as part of Emergency Supplemental Funding to help reduce the effects of the Iraqi War of 2003 on Jordan's economy and to enhance its security and stability.

Jordan is also the recipient of small grants from the Nonproliferation, Anti-Terrorism, Demining, and Related Programs account (NADR) for U.S. antiterrorism assistance (Sharp, April 9, 2010). Since FY 2002, Jordan has received an average of about $\$ 2$ million a year in NADR appropriations from Congress. NADR funding is earmarked to aid training of civilian security and law enforcement personnel from "friendly governments" in police maneuvers to more effectively deal with terrorism (Sharp, WikiLeaks, October 17, 2008).

Amaney A. Jamal, in her book, Of Empires and Citizens: Pro-American Democracy or No Democracy at All? (2012), stated the following:

After the events of 9-11, Jordan has also grown more dependent on the United States for security. As [King] Abdullah [II] turned to the United States to energize the Jordanian economy further, Amman also became more useful to the United States, providing intelligence on al-Qaeda after 9-11. Further, Jordan served as a key site from which the U.S. military could launch its devastating attack on Iraq in 2003 (Jamal, 2012, p. 51).

In March 2003, Jordan joined what was identified as the "Coalition of the Willing" (Christoff, 2007, p. 1). As a result, it was the second largest funding recipient, receiving \$295 million of additional U.S. support to Non-U.S. Coalition Troops from March 2003 through March 2007 for border operations. Since 2003, Jordan has received about \$1.34 billion in security assistance from the U.S. (Christoff, 2007).

As a result of supplemental appropriations acts (a total of $\$ 1.78$ billion since FY 2003), annual U.S. military assistance to Jordan has increased significantly from a total of $\$ 69.9$ million in FY 1990 to $\$ 429.0$ million in FY 2018. In addition to the noted funds specified for Jordan, the country has also received funds from emergency supplemental bills passed to reimburse Pakistan, Jordan, and other key cooperation states for logistical expenses for supporting U.S. military operations. Increased aid is a direct reflection of the Bush administration's gratitude for Jordan's role in fighting terrorism and renovation of Iraq. It also may be an indirect nod to Jordan's exposure in a volatile region that is very close to the instability in Iraq and conflict between the Israelis and Palestinians (Sharp, WikiLeaks, October 17, 2008).

It is pertinent to point out that the annual U.S. large-scale military assistance grants to Jordan considerably helped upgrade its standard military weapon systems and increase its military's qualification and readiness. Jordan received an average of about \$260 million in FMF between 2007 and 2010, as well as \$12.9 million in IMET, and \$245 million in FMF as part of Supplemental Emergency Assistance. In return, Jordan contributes significantly to the United Nations peacekeeping forces in numerous crisis-smitten areas across the globe, hailing as the top supplier of police personnel. Jordan additionally provided 57,000 military troops to eighteen peacekeeping missions around the world (Sharp, April 9, 2010).

Since the fall of Saddam Hussein's regime in 2003, Jordan has helped the U.S. restore stability and security to Iraq. Jordan provided valuable intelligence regarding Al-Qaeda and its leaders and other insurgent groups. Also, Jordan trained Iraqi police in Jordan, hosted several hundred thousand Iraqi refugees, and has worked closely with donor agencies and international organizations. These efforts have helped address the Iraqi refugees' humanitarian needs, dispatching a military medical field hospital. In August 2008, Jordan sent an ambassador to Iraq to enhance the bilateral relations.

From 2011 to 2014 U.S. military assistance to Jordan increased rapidly. Jordan received an average of about \$296 million in FMF and \$3.649 million in IMET. Immediately following the emergence of the Islamic State of Iraq and Syria (ISIS) in 2013, the U.S. military assistance to Jordan increased significantly to control the threat of ISIS, to secure the borders, and to maintain the country stability. In this regard, it is important to point out that the US-led coalition of Western and Middle Eastern countries commenced air strikes against the Islamic State (IS) in Iraq in August 2014 and Syria a month later.

In September 2014, Jordan joined the U.S. and several Arab Gulf states in carrying out air strikes on IS fighters in Syria to ensure the security and stability of its borders. In response, the IS threatened to "break down" Jordan's borders, security, and stability. 


\section{Jordan Susceptible to Emotional Response}

Jordan was one of four Arab states taking part in air strikes against ISIS, bombing 56 ISIS targets in Syria over three days following the death of the 26-year-old Jordanian air force pilot, Muaath al-Kasasbeh. The campaign hurt ISIS somewhat, but the retaliation has raised concerns that Jordan could be drawn into further clashes. "By exposing its role in the air strikes and the coalition, the threat has become more intense," says Hasan Abu Hanieh, "an Amman-based analyst who specializes in Islamist groups." For example, the video of the killing of al-Kasasbeh was used by ISIS to bait Jordan, according to Abu Hanieh. "ISIS wanted to provoke Jordan into attacking it. It is important for them to create chaos in the country," he says. "In response to any Jordanian attack, ISIS would say it is defending itself. Jordan fell halfway into this trap." (Ma'ayeh, 2015).

Since Jordan joined the Western-regional powers coalition, ISIS increased its claims of responsibility for several recent terrorist attacks in Jordan, including: five people in a Palestinian camp near Amman; six Jordanian security personnel in a suicide truck bombing attack near a makeshift refugee camp on the border with Syria in Rukban area; and ten people in a terrorist attack in the southern Jordanian city of Karak according to local newsagents. This last attack included the head of the military's special forces (Sweis, December 20, 2016).

In 2005, many years before the killing of Jordanian pilot al-Kasasbeh, Abu Musab Al-Zarqawi (the founder of the group that became ISIS) planned and carried out a triple suicide bombing over Amman that killed 57 people. Later, Zarqawi, originally from Zarqa in Jordan, was killed in a U.S. airstrike in Iraq in 2006.

Government officials estimate 2,000 Jordanians are fighting with ISIS and could return to their home country to carry out additional attacks. As many as $10 \%$ of Jordan's 6.5 million residents view ISIS positively, found a poll by the Center for Strategic Studies at the University of Jordan conducted in 2014 (Ma'ayeh, 2015).

Further, ISIS sympathizers have threatened revenge for Jordan's airstrikes on social media. In response, the government extended its anti-terrorism legislation to criminalize online supporters of ISIS in addition to fortifying borders with Iraq and Syria. Mohammad Momani, the government's spokesman, says the country continues to shore up its borders: "It is the sovereign right of countries to move troops as necessary." (see Map 1).



Source: Map adopted from HIS Conflict Monitor as quoted in BBC News.

According to the Jordanian government spokesman, the ISIS group enjoyed the support of a growing number of people in the kingdom, some of whom staged demonstrations in the southern town of Maan, whose residents hoisted the black flag used by ISIS in the main square in July 2014 (BBC News, December 3, 2015).

Resulting from the Syrian Civil War and Operation Inherent Resolve against ISIS, the U.S. increased military assistance to Jordan and funnelled the funds through Defense Department-managed accounts. Jordan still receives the majority of U.S. military assistance from the FMF account, but Congress has authorized additional funds to bolster Jordan's border security from various accounts, including:

(i) Section 1206/10 U.S.C. 2282 Authority to Build Partner Capacity, (ii) the Counterterrorism Partnerships Fund (CTPF), and Department of Defense Operations \& Maintenance Funds (O\&M). Activities permitted under 10 U.S.C. 2282 have been incorporated into a new, broader global train and equip authority established by Section 1241 (c) of the FY2017 NDAA: 10 U.S.C. 333.

Military aid provided by these accounts is generally coordinated through a joint Defense Department (DOD)-State Department (DOS) review and approved by Secretary of Defense, with the concurrence of the Secretary of State (Sharp, November 14, 2017, pp. 15-16). 
In FY 2015, Jordan received \$385 million in FMF and \$3.8 million in IMET. The U.S. and Jordan have established a five-year plan to prioritize Jordan's needs and procurement budget using congressionally-appropriate FMF. Proposed arms sales including 35 Meter Coastal Patrol Boats; M31 Unitary Guided Multiple Launch Rocket Systems (GMLRS) Rocket Pods; UH-60M VIP Blackhawk helicopter; and repair and return of F-16 Engines. On February 18, 2016, President Barack Obama signed the U.S.-Jordan Defense Cooperation Act of 2015, which authorize furthered review and an increased the value threshold for intended arms sales to Jordan for three years. In FY 2016, Jordan received $\$ 450$ million in FMF and \$3.733 million in IMET, increasing to \$470 million in FMF and \$3.879 million in IMET in FY 2017. The U.S. delivered two S-70 Blackhawk helicopters to Jordan, totalling up to 26 Blackhawk aircraft in July 2017. More recently, in FY 2018, Jordan received an estimated \$425 million in FMF and \$4.0 million in IMET (Sharp, November 14, 2017, p. 15).

\section{Conclusion}

This paper reviewed the impact of the U.S. military assistance on the political stability in Jordan from 1990 to 2018. The U.S. military assistance to Jordan dates back decades to the early years of the Cold War. This paper explored that the U.S. military assistance to Jordan is a critical component in bilateral relations. The U.S. military assistance is principally directed toward enabling the JAF to procure and maintain a conventional weapons system. Also, the U.S. military assistance to Jordan has increased rapidly after 9/11 events of 2001, the Iraq War of 2003, and the rise of ISIS in 2013 to secure the borders, to maintain the country stability, and to control the threat of ISIS.

Furthermore, the U.S. military assistance was a reward to Jordanian government because it has played a prominent role in the U.S.-led coalition against ISIS. By providing military, logistical, and intelligence support. Today, Jordan is in the top of military assistance recipients in the world, receiving up to \$19.2 billion through FY 2016.

\section{References}

Christoff, Joseph A. (May 9, 2007). Stabilizing and Rebuilding Iraq: Coalition Support and International Donor Commitments, GAO Report GAO-07-827T (pp. 1-12). Washington, DC: US Government Accountability Office.

Fry, Michael G., Erik Goldstein, and Richard Langhorne, (Eds.) (2002). Guide to International Relations and Diplomacy (P. 9). London: Continuum.

Jamal, Amaney A. (2012). Of Empires and Citizens: Pro-American Democracy or No Democracy at All? (pp. 47-51). Princeton, NJ: Princeton University Press.

Joshua, W., and Stephen P. Gibert. (1969). Arms for the Third World: Soviet Military Aid Diplomacy (p. 130). Baltimore, MD: The Johns Hopkins Press.

Islamic State: Where key countries stand. (2015). [Online]. Available: https://www.bbc.com/news/world-middle-east29074514.

Khader, B., and Adnan Badran, (Eds.). (1987). The Economic Development of Jordan (pp. 18-20). London: Croom Helm.

Knowles, W. (2005). Jordan since 1989: A Study in Political Economy (p. 127). New York: I.B. Tauris \& Co Ltd.

Ma'ayeh, Suha. How Jordan Got Pulled Into the Fight Against ISIS. (2015). [Online]. Available: http://time.com/3721793/jordan-fight-against-isis/.

Sharp, Jeremy M. (November 14, 2017). Jordan: Background and U.S. Relations, CRS Report RL33546 (pp. 12-16). Washington, DC: Library of Congress, Congressional Research Service.

. Jeremy M. (December 2, 2014). Jordan: Background and U.S. Relations, CRS Report RL33546 (p. 13). Washington, DC: Library of Congress, Congressional Research Service.

. Jeremy M. (June 15, 2010). U.S. Foreign Assistance to the Middle East: Historical Background, Recent Trends, and the FY2011 Request, CRS Report RL32260 (p. 7). Washington DC: Library of Congress, Congressional Research Service.

. Jeremy M. (April 9, 2010). Jordan: Background and U.S. Relations, CRS Report RL33546 (pp. 23-26). Washington, DC: Library of Congress, Congressional Research Service.

Jeremy M. (October 17, 2008). WikiLeaks Document Release: Jordan, CRS Report RL33546 (p. 20). Washington DC: Library of Congress, Congressional Research Service.

Shaw, J. Inside ISIS: A Time Special Report. (2018). [Online]. Available: http://time.com/inside-isis-a-time-special-report/.

Sweis, Rana F. ISIS Is Said to Claim Responsibility for Deadly Attack in Jordan. (2016). [Online]. Available: https://www.nytimes.com/2016/12/20/world/middleeast/jordan-attack-isis-karak.html.

Times Staff and Wire Reports. (June 20, 1991). World in Brief: House Votes to Halt Jordan Military Aid. Los Angeles Times. 